\title{
A Perceptual Study of Phonological Variations in Pakistani English
}

\author{
Abdul Malik Abbasi ${ }^{1}$, Mansoor Ahmed Channa ${ }^{2}$, Innayatullah Kakepoto ${ }^{2}$, Rida Ali $^{1} \&$ Misbeh Mehmood $^{1}$ \\ ${ }^{1}$ Sindh Madressatul Islam University, Karachi, Pakistan \\ ${ }^{2}$ Quaid-e-Awam University of Engineering, Science \& Technology Nawab Shah, Sindh, Pakistan \\ Correspondence: Abdul Malik Abbasi, Sindh Madresstul Islam University, Karachi, Pakistan. E-mail: \\ amabbasi@smiu.edu.pk
}

Received: September 24, 2017 Accepted: November 1, 2017 Online Published: December 23, 2017

doi:10.5539/ijel.v8n2p92 URL: http://doi.org/10.5539/ijel.v8n2p92

\begin{abstract}
The present study examines the perceptual judgments of English lexical items and English lexical stress by Urdu ESL (Note 1) (English as Second Language) learners. The analysis discusses the different sound systems of both languages and their syllabification system coupled with the stress patterns. The stimuli of 50 high frequency English words were designed as data collection tool for counting the number of syllables and for marking lexical stress as follows: 9 monosyllabic, 11 disyllabic, 10 tri-syllabic, 10 four-syllabic and 10 five-syllabic words. All participating subjects were 40 under graduate students from the department of computer sciences, Sindh Madressatul Islam University (SMIU) Karachi. The findings of the study show English lexical items were syllabified with different numbers and primary stressed syllables were also marked with different places of the lexical items, however, data also show the correct syllabification and the right placement of lexical stress which is a strong evidence manifesting as Urdu-accented English perceived and produced by Urdu ESL learners.
\end{abstract}

Keywords: ESL learners, Urdu accent, syllable, stress, rhythm

\section{Introduction}

The paper is based on a study conducted to investigate the intuition of Urdu speaking learners of English regarding the perception and production of English speech. It was hypothesized that Urdu speaking English learners make phonological variations in terms of stress and syllable patterns in the production of English speech. The present psycholinguistic analysis aims to investigate the awareness of English stress and syllable patterns among Urdu speakers who are learning English as Second Language, by eliciting judgments of the number of syllables and the location of primary stress from undergraduate students at Sindh Madressatul Islam University, Karachi.

There is a relatively large difference in stress systems of English and Urdu languages because both are written and spoken with different orthography and with different phonetic and phonological rules. Both languages also contain different number of sounds i.e., vowels and consonants. Urdu has phonemic writing system wherein the spelling of the word transparently represents its pronunciation, whereas "English is non-phonetic language so English spellings may be misleading" as noted by Ladefoged (2004). English is an international language of business and communication, which is widely spoken in various accents known as World Englishes. English is chiefly spoken in different accents by speakers of different languages (different mother tongues) in Pakistan i.e., Urdu-accented, Sindhi-accented in Sindh and Punjabi-accented in Punjab and Pashto-accented in Khyber Pakhtunkhwa. In Urdu-accented English, the lexical stress is shifted in accordance with Urdu stress pattern regarding their lexical items and the lexical rhythm is relatively more affected rather than other aspects of English speech as hypothesized in this paper. Languages have different sound systems with various rules of pronunciations and the intonation of speech. "Stress is the emphasis on a sound or syllable by pronouncing it more loudly than other syllables in the same word string whereas, intonation is the rising or falling pitch of voice while pronouncing a word or speech" as noted by Ali (2009).

English consists of 44 standard sounds i.e., 24 consonantal sounds and 20 vocalic sounds. Eight are diphthongs and 12 are pure vocalic sounds. Roach (2004, as cited in Abbasi, 2012) states there are 24 English consonants /p, $\mathrm{b}, \mathrm{t}, \mathrm{d}, \mathrm{k}, \mathrm{g}, \mathrm{m}, \mathrm{n}, \mathrm{y}, \mathrm{t}, \mathrm{d}, \mathrm{f}, \mathrm{f}, \mathrm{v}, \theta, \mathrm{d}, \mathrm{s}, \mathrm{z}, \int, 3, \mathrm{~h}, \mathrm{r}, \mathrm{j}, \mathrm{v}, \mathrm{w}, \mathrm{l} /$ and 20 vocalic sounds as follows:/er, aI, गI, əv, av, Iə, eə, və, i, I, 3:, ə, u, $v, \mathrm{e}, \Lambda$, ə:, æ, a, p/. English alphabet contains 26 Roman letters which is an orthographic representation of 26 sounds only, however, International Phonetic Association IPA (1999), illustrates all English 
sounds representation in IPA symbols. Whereas, Urdu contains fourteen oral vowels-seven long and seven short vowels as argued by Bokhari (1985). Hussain (2010) contends that stress in Urdu is associated with the syllable weight and the syllable weight corresponds to mora count. Long vowels are equal to two moras; whereas short vowels are a single mora. In addition, each coda consonant has a weight equivalent to a single mora. Masica (1991) states that generally in New Indo-Aryan (NIA) languages stress is predictable and stress is assigned by utilizing some constraints i.e., etymology, morphology, word classes, and syllable weight. In NIA languages, the patterns of stress vary from language to language and these NIA languages are not stress-timed but syllable or mora-timed. Hindi-Urdu is in the Indo-Aryan family, a major sub-branch of Indo-European. The national language of India is Hindi whereas, the national language of Pakistan is Urdu. Hindi differs from Urdu in terms of literary styles and linguistic aspects as noted by Masica (as cited in Nayyar, 2000-2001). Hindi-Urdu can be described as two sides of the same coin in terms of quite similar behavior about phonetic and phonological aspects.

In addition, Urdu words are not differentiated regarding stress alone since stress is not distinct in Hindi-Urdu. Stressed syllables are related to syllable weight, such as in the word, kəla 'art'; whether stressed as kə'la or unstressed as kəla', it has the same meaning. The phonetically long syllables are basically the stressed syllables and their length is retained without any position in a word as argued by Nayyar (2000-2001). Dyrud (1997) notes that stress is a relatively prominent syllable than the neighboring syllables at word level. The location of stress is marked in some Hindi and Urdu dictionaries i.e., Fallon (1879) and Qureshi (1992). Stress pattern in Hindi-Urdu verse was noted by Fairbanks (1981, as cited in Dyrud, 1997) which shows that the location of word stress is predictable based on syllable weight. In addition, Hussain (1997, as cited in Dyrud, 1997) notes that when there are light syllables in a word string then the penultimate syllable is stressed and if final syllable is heavy, then the stress is assigned on final heavy. Urdu also exhibits extrametricality phenomenon, where the final mora carries no weight and is not counted in assigning the stress location.

Lexical stress is considered as relatively more prominent stress among the syllables in a word. Prominence is normally indicated by such features such as amplified loudness and vowel length, and modifications in pitch contours. Some languages have fixed stress, which means the lexical stress falls on the same location in every word, for example, the first or the penultimate etc. Stress in English is less predictable, and is determined in part by morphological factors. Some languages are considered to have no lexical stress at all whereas some other languages are considered "to have light stress, like Sindhi, which is light-stress language" as noted by Abbasi \& Hussain (2015)

Ali (2009) claims that 'Pakistani students do not get enough chance to go through proper study of English speech-sounds. Therefore, they do not recognize them properly. Instead they try to match them with speech-sounds of Urdu which ultimately corrupt their English pronunciation. Pakistani students pronounce most English words in an Urdu accent which spoils their image while speaking in front of public or while communicating with any outsider'.

Nyyar (2000-2001) notes that Urdu is described as having 10 syllable structures and as in other languages, Urdu contains only a single stress in a word. However, in some places multiple stresses were also reported. Syllables are classified as follows: heavy, medium and light. The greater the weight of syllable, the stronger the possibility of primary stress on lexical level. Much work has been conducted on Urdu in terms of phonetics and phonology. Hussain (2010) contends that the lexical stress alters the phonetic properties of both vowels and consonants in Urdu. This was the first such acoustic study of lexical stress in Urdu. Other research on the phonology of Urdu has included Phonemic Inventory, Urdu templates, and the Urdu sound system conducted by Hussain (2010).

Hussain (2010) conducted an acoustic analysis of Urdu stress using recordings of Urdu native speakers as its measurement for determining the lexical stress in Urdu. He applied acoustic realizations of vowel duration, their fundamental frequency, relative intensity, and first two formant frequencies of six long and three short vowels of Urdu. Hussain argues that Urdu has lexical stress, which is often marked on a final heavy syllable. However, the final heavy syllable does not contribute to the weight of a final syllable because of extrametricality. Urdu is a fixed stress language since syllable weight determines the primary stress in a word. Phonetic analysis shows that the quality of vowels is not only affected by stress, but also that phonetic properties of stop closures are modified by the stress. Masica (1991) regards Urdu and Hindi as the same language whereas, Hussain's (2010) analysis in terms of vowel quality as measured for Urdu is different from Hindi.

Rahman (2014) contends that variation from Received Pronunciation (RP) comes from prosodic transmission from mother tongue. Nelson (1982) argues that most of the languages spoken in South Asia are syllable-timed, whereas, English is stress-timed (as cited in Rahman, 2014). This makes Pakistani English a different one in 
terms of rhythm from the Received Pronunciation. He further notes that there are negligible variances in the rhythm and the stress pattern of Punjabi and Urdu in comparison to English. Pakistani speakers of English have also different intonation from RP speakers (Rahman, 2014).

After looking at variations in the stress patterns of Urdu and English along with other differences in syllable structure and phoneme inventory, the question is raised as to what kind of stress and syllable patterns Urdu speaking English language learners assign to English words. The question has not been explored yet, therefore the study tests the hypothesis that Urdu ESL learners judge syllable count and stress location in English words differently than they are specified in the dictionary, and differently from speakers of RP.

\section{Method}

\section{Research Participants}

For data collection, the participants were selected from the department of computer sciences; they were undergraduate students from Sindh Madressatul Islam University Karachi studying second, third and fourth years. Total subjects were 40 ( 20 male and 20 female) their ages ranged from 17 to 25 .

\subsection{Material}

Stimuli of 50 English lexical items were looked up from the Cambridge English pronouncing dictionary (2005) and the list of stimuli were randomly selected as 9 mono-syllable, 11disyllable, 10 tri-syllable, 10 four syllable and 10 five syllable lexical items.

\subsection{Procedure}

The subjects were given a brief explanation about English syllables and their primary stress in English lexical items. They were detailed for example as follows: "Heart" is one syllable, "Police" two syllables and "Banana" three syllable lexical items. In addition, they were also asked to mark any of three options per their intuition first as to how many syllable numbers are in English word. Similarly, they were also asked to mark primary stressed syllable from multi-syllable words as to which number (first, second or third) of syllable is stressed relatively. They were explained to syllabify and to mark primary stress in English words as follows:

Table 1. Syllable counts and stress judgments

\begin{tabular}{lllll}
\hline SN & Syllable Counts & & Stress Syllables & \\
\hline 1 & Soul & & Soul & \\
& One & Soul & So-ul & 1 st \\
& Two & So-ul & So-ul & 2nd \\
& Three & So-u-al & So-u-al & 3rd \\
\hline 2 & Flower & & Flower & \\
& One & flower & flower & 1 st \\
& Two & flo-wer & flo-wer & 2nd \\
& Three & flo-w-er & flo-w-er & 3rd \\
\hline
\end{tabular}

\subsection{Syllable Level Data Analysis}

Counting of syllables is very basic and common practice for learning correct pronunciation of a word in any language. The study aims to investigate the linguistic judgements of the speakers of English as second language learners how they syllabify English lexical items. As illustrated in Figure 1, nine mono-syllabic words were syllabified as either mono-disyllabic, or sometimes as tri-syllabic words by Urdu speaking learners of English. 


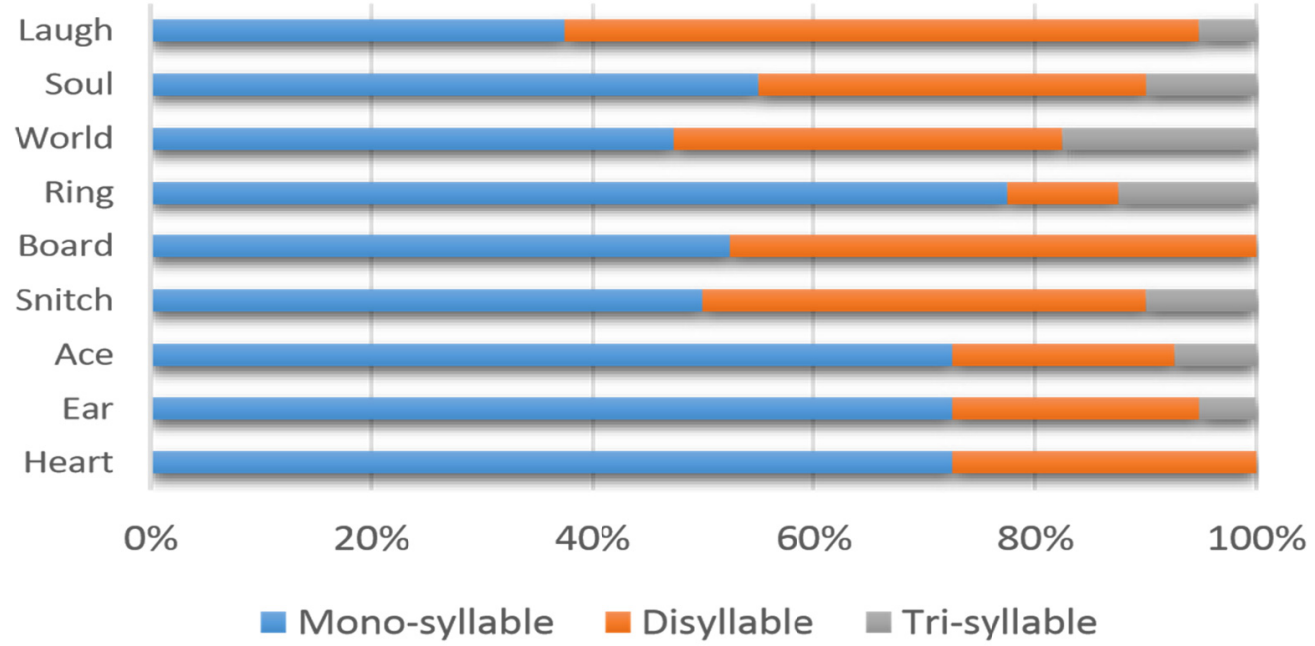

Figure 1. Nine mono-syllabic English words were syllabified differently

As shown in Figure 1, the words 'heart 'ear 'ace and ' ring were reported as monosyllabic in $75 \%$ of the responses or more. Board word was reported as mono-syllable by 53 percentage whereas, 47 percentage reported as disyllable. Tri-syllable words were reported between 5-18 percentage of responses and all words were reported as disyllabic in as many as $25 \%$ of responses by Urdu native speakers.

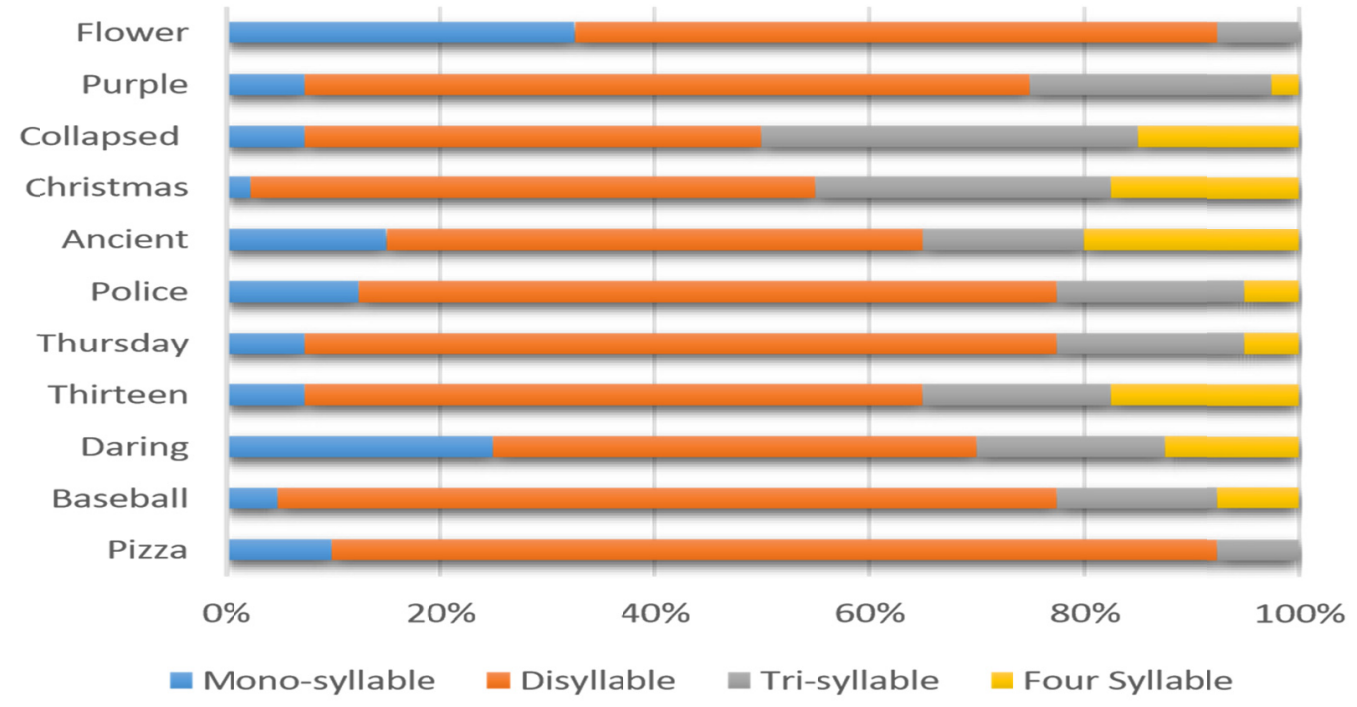

Figure 2. Eleven English di-syllable were syllabified differently across English words

Figure 2 illustrates around $80 \%$ of responses aggregated over eleven disyllabic words reported these words as having two syllables, while $20 \%$ of responses reported the same words as having three or four syllables. Figure 3 illustrates between $5-12 \%$ of responses as four syllable words, while $41 \%$ to 65 responses to as tri-syllabic words, $10-38 \%$ as disyllabic and $1-10 \%$ mono-syllabic words. 


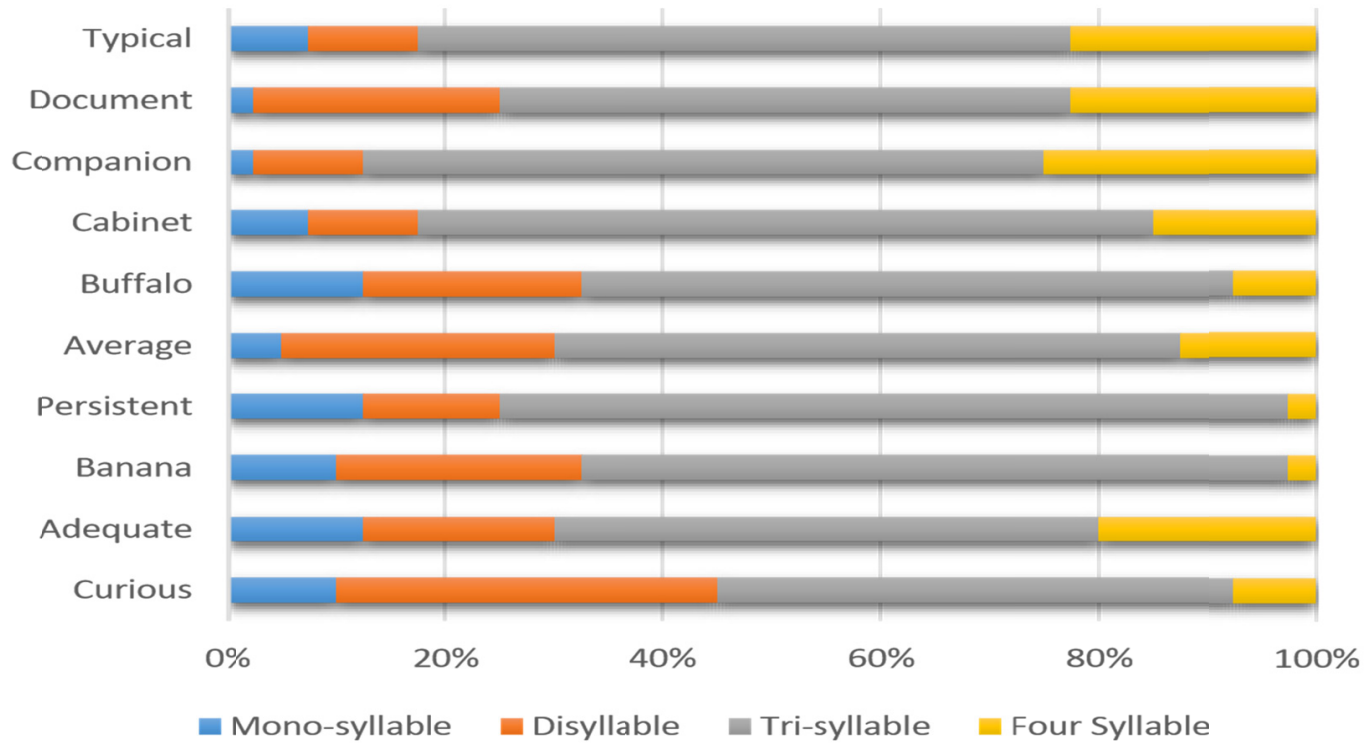

Figure 3. Ten tri-syllabic words were syllabified across English words

Ten four syllabic words were syllabified between $0-6 \%$ as monosyllabic, 3-7 \% as disyllabic, $5-21 \%$ as tri-syllabic, $17-33 \%$ as four syllabic words. Ten four-syllabic words were syllabified across English words as the data illustrate five syllabic words were marked as five syllabic between 18-75\% Urdu speaking English learners, between $10-58 \%$ as four syllabic, $10-18 \%$ as tri-syllabic, $4-20 \%$ while $3-10 \%$ as mono-syllabic words.

\subsection{Lexical Stress Analysis}

Similarly, the same list was also marked by the same subjects for primary stress on fifty mono/multi-syllable English lexical items. There are nine mono-syllabic words whose syllables were stressed as follows: 30 to $62 \%$ were marked on first syllable, 21 to $57 \%$ marked on second syllable while 8 to $36 \%$ marked on third syllable as illustrated in Figure 4.

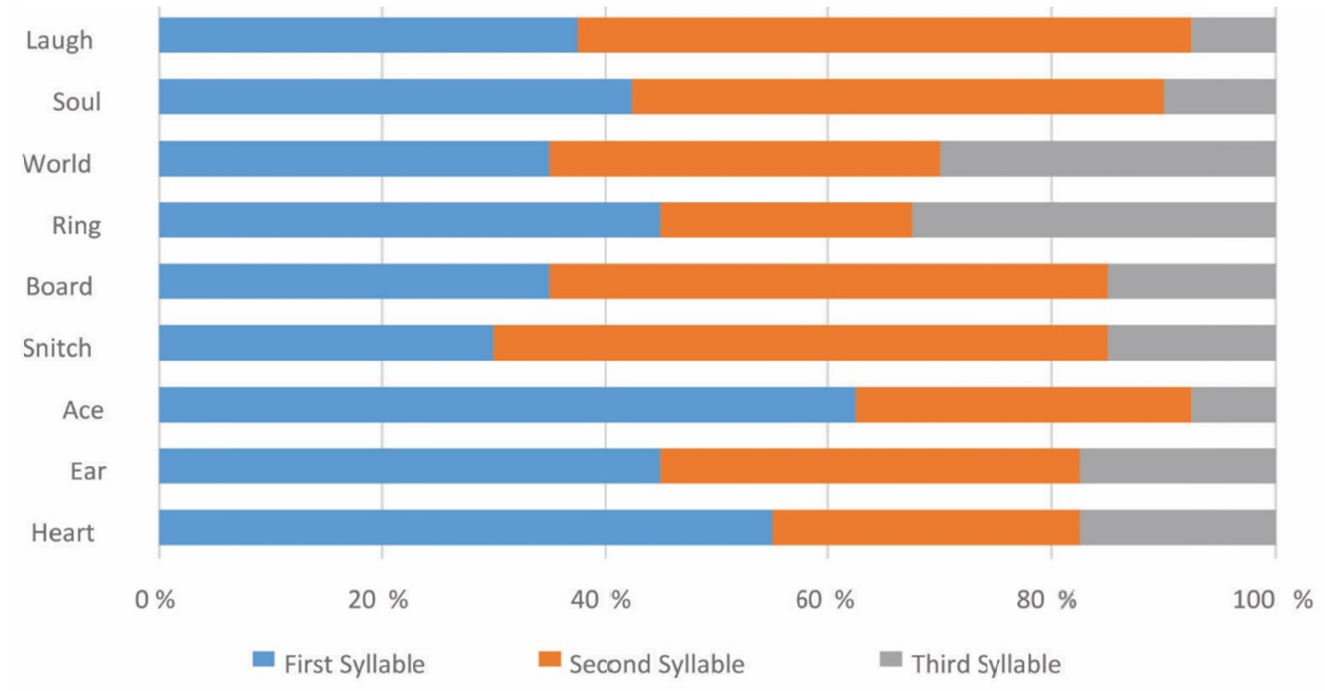

Figure 4. Stress was marked across nine English words

There are eleven disyllabic words whose syllables were stressed as follows: 18 to $60 \%$ were marked on First syllable as primary stressed syllable, 23 to $60 \%$ marked on Second syllable as stressed while 3 to $10 \%$ marked on third syllable as stressed and 5 to $20 \%$ marked on fourth syllable stressed as illustrated in Figure 5. 


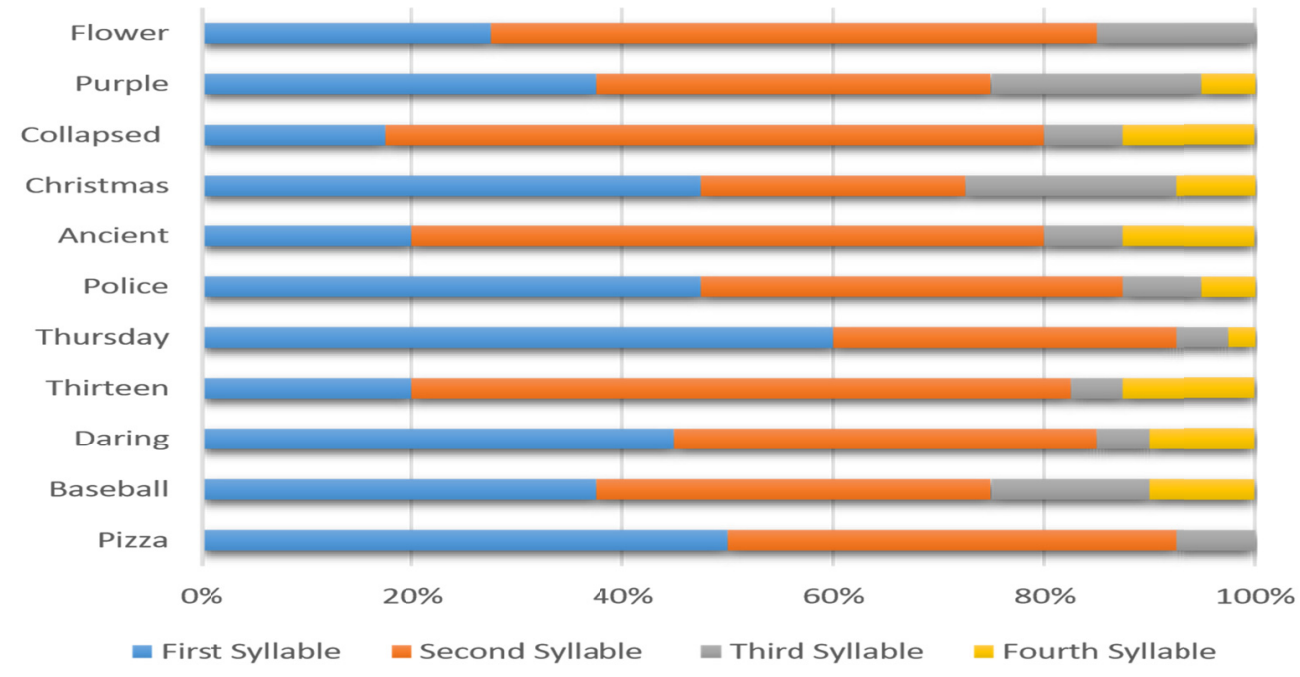

Figure 5. Stress was marked across eleven di-syllabic English words

There are ten tri-syllabic words whose syllables were stressed as follows: 20 to $57 \%$ were marked on First syllable as primary stressed syllable, 12 to highest $63 \%$ marked on Second syllable as stressed, 5 to $55 \%$ marked on Third syllable as stressed while lowest 3 to $20 \%$ marked on Fourth syllable as stressed syllable as illustrated in Figure 6.

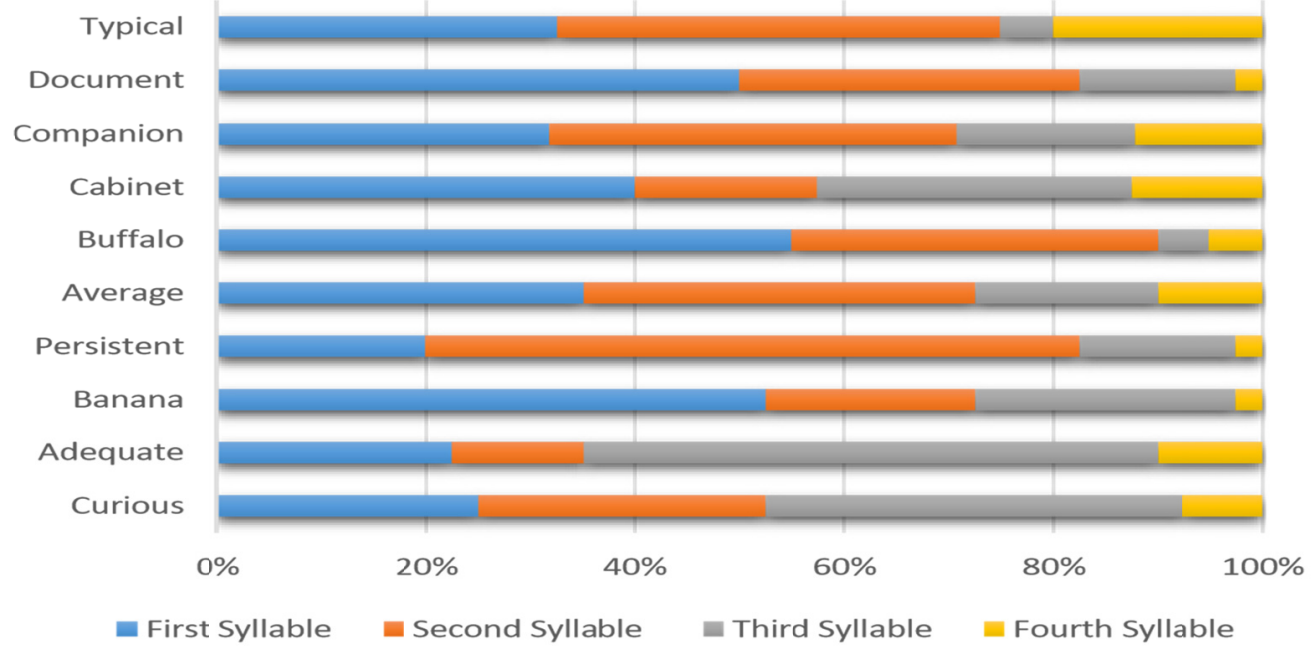

Figure 6. Primary stress was marked across tri-syllabic ten English words

There are ten four-syllabic words whose syllables were stressed as follows: 7 to $45 \%$ were marked on First syllable as primary stressed syllable, 20 to $43 \%$ marked on Second syllable as stressed, 5 to $40 \%$ marked on Third syllable as stressed, 3 to $52 \%$ marked on Fourth syllable as stressed while 5 to $27 \%$ marked on Fifth syllable as stressed syllable as illustrated in Figure 7. 


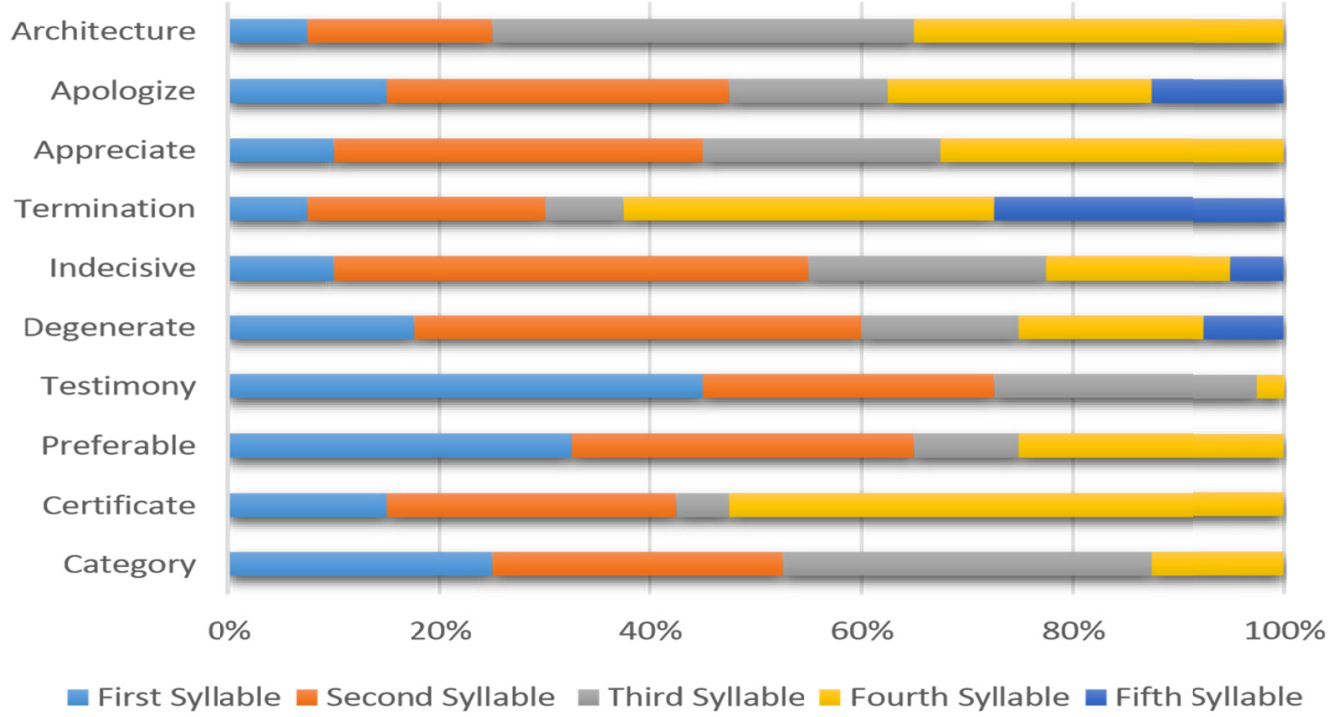

Figure 7. Stress was marked across five syllabic ten English words

There are ten five-syllabic words whose syllables were stressed as follows: Between 5 to $43 \%$ were marked on First syllable as primary stressed syllable, 12 to $59 \%$ marked on Second syllable as stressed, 10 to $41 \%$ marked on Third syllable as stressed, 5 to $23 \%$ marked on Fourth syllable as stressed, 5 to $28 \%$ marked on fifth as stressed while $13 \%$ marked on Sixth syllable as stressed syllable as illustrated in Figure 8.

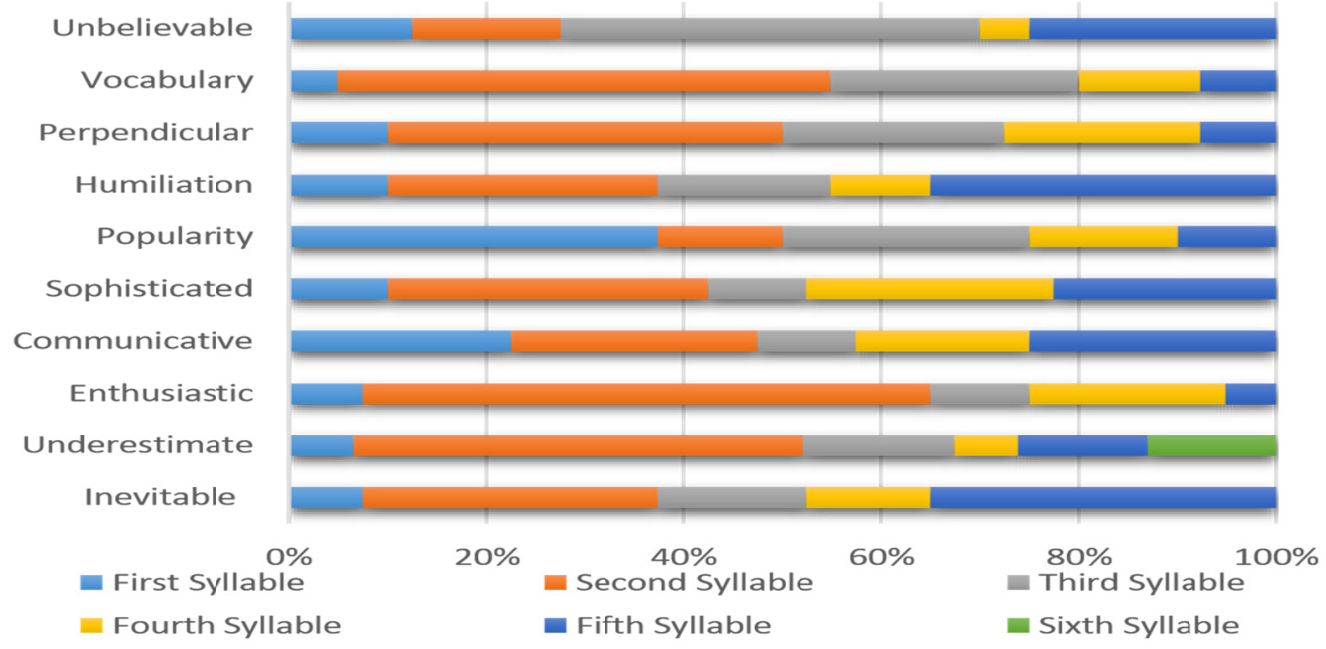

Figure 8. Primary stress was marked across ten English words

\section{Results}

Since Urdu is a national language and mother tongue of most of Pakistanis so these ESL learners blend pronunciation of English with Urdu-accent or Sindhi accent noted by Abbasi \& Kimball (Under review, 2017). Languages carry their own sound systems therefore native speakers of language have their articulatory settings with their native sounds in words which effect on the production of second language like English. The perceptual judgments of 40 subjects proved the hypothesis was true: Urdu speaking learners of English perceive English influenced by Urdu phonology. As illustrated in Figure 1, nine mono-syllabic words were syllabified as either mono-disyllabic, or sometimes as tri-syllabic words by Urdu speaking learners of English. Figure 2 illustrates around $80 \%$ of responses eleven disyllabic words reported these words as having two syllables, while $20 \%$ of responses reported the same words as having three or four syllables. Figure 3 illustrates between $5-12 \%$ of 
responses as four syllable words, while $40 \%$ to 65 percentage of responses as tri-syllabic words, $10-38 \%$ as disyllabic and 1-10\% mono-syllabic words. Ten four syllabic words were syllabified between $0-6 \%$ as monosyllabic, 3-7 \% as disyllabic, $5-21 \%$ as tri-syllabic, $17-33 \%$ as four syllabic words. Ten four-syllabic words were syllabified across English words as the data illustrate five syllabic words were marked as five syllabic between 18-75 \% Urdu speaking English learners, between 10-58 \% as four syllabic, $10-18 \%$ as tri-syllabic, 4-20\% while 3-10\% as mono-syllabic words. Most of the words were high frequency words spoken by ESL learners in Pakistan as noted by the author.

Additionally, the primary stress syllables were judged in nine monosyllabic English words, the subjects marked primary stress either on first syllable, second syllable or on third syllable by Urdu speaking learners of English. There are nine mono-syllabic words whose syllables were stressed as follows: 30 to $62 \%$ were marked on first syllable, 21 to $57 \%$ marked on second syllable while 8 to $36 \%$ marked on third syllable as illustrated in Figure 4. There are eleven disyllabic words whose syllables were stressed as follows: 18 to $60 \%$ were marked on First syllable as primary stressed syllable, 23 to $60 \%$ marked on Second syllable as stressed while 5 to $20 \%$ marked on third syllable as stressed and 5 to $20 \%$ marked on fourth syllable stressed as illustrated in Figure 5 .

There are ten tri-syllabic words whose syllables were stressed as follows: 20 to $57 \%$ were marked on First syllable as primary stressed syllable, 12 to $63 \%$ marked on Second syllable as stressed, 5 to $55 \%$ marked on Third syllable as stressed while 3 to $20 \%$ marked on Fourth syllable as stressed syllable as illustrated in Figure 6 . There are ten four-syllabic words whose syllables were stressed as follows: 7 to $45 \%$ were marked on First syllable as primary stressed syllable, 20 to $43 \%$ marked on Second syllable as stressed, 5 to $40 \%$ marked on Third syllable as stressed, 3 to $52 \%$ marked on Fourth syllable as stressed while 5 to $27 \%$ marked on Fifth syllable as stressed syllable as illustrated in Figure 7. There are ten five-syllabic words whose syllables were stressed as follows: Between 5 to $43 \%$ were marked on First syllable as primary stressed syllable, 12 to $59 \%$ marked on Second syllable as stressed, 10 to $41 \%$ marked on Third syllable as stressed, 5 to $23 \%$ marked on Fourth syllable as stressed, 5 to $28 \%$ marked on fifth as stressed while $13 \%$ marked on Sixth syllable as stressed syllable as illustrated in Figure 8. Most of the words were high frequency words spoken by English native speakers and by ESL learners in Pakistan.

\section{Conclusion}

The perceptual study concludes that Urdu speaking learners of English syllabify English words with the different number of syllables in English words and assign different stress location in English words. Thus, the Second Language Learners perceive English speech with different syllable and stress patterns than those specified in the dictionary, which correspond to native speakers of RP English. The study concludes that Urdu speaking learners of English make phonological variations in English as determined in the study and the same also noted for Sindh speaking learners of English words (Abbasi, 2017). It maybe because of a bit weak intuition of lexical stress in their native words which ultimately effects on second language learning though, English is considered as a stress-timed language. In addition, the hypothesis was accepted as it has been confirmed that Urdu speaking of English learners perceive phonological variations since the study discovered the evidence of syllable and stress intuitive judgments of fifty English words. Thus, the English words were syllabified with less or more syllable-lexemes and stress-shift was also strong evidence for the phonological variations.

\section{References}

Abbasi, A. M., \& Amelia, K. (Under review, 2017). Awareness of L2 American English word stress: Implications for teaching speakers of Indo-Aryan languages. Manuscript submitted for review.

Abbasi, A. M., \& Hussain, S. (2015). Phonetic analysis of lexical stress in Sindhi. Sindh University Research Journal-SURJ, 47(4), 749-756.

Abbasi, A. M, \& Hussain, S. (2015). The role of pitch between stress and intonation in Sindhi. Annual Research Journal of English Language Forum, 17, 9-24.

Abbasi, A. M. (2017). The stress pattern of Sindhi and English. Munich. Lincom Europa, Germany.

Abbasi, A. M., \& Hussain, S. (2012). Syllable structure and syllabification in Sindhi-English loanwords. International Journal of Researchers, 1(4), 120-134.

Ali, S. A. (2009). Difficulties faced by Pakistani students in pronouncing English words, their factors and solutions. Retrieved from https://www.scribd.com/doc/20874038/Problems-faced-byPakistani-English-speakers-in-Pronunciation-ofEnglish-their-factors-and-solutionsPhonetics-Phonology-Assignment-NUML 
Bokhari, S. H. (1985). Regional accents of English. Retrieved from http://en.wikipedia.org/wiki/Regional_accents_of_English

Crystal, D. (2008). A dictionary of linguistics and phonetics (6th ed.). New York, USA: Black Willey. https://doi.org/10.1002/9781444302776

Dee, J. (2004). Problems Faced by Pakistani English Speakers. Retrieved from http://www.scribd.com/doc/61583421/Problems-Faced-by-Pakistani-EnglishSpeakers

Dyrud, L. (1997). Hindi-Urdu: Stress accent or non-stress accent (Unpublished master's thesis). University of North Dakota, Grand Forks, ND. Retrieved from https://arts-sciences.und.edu/summer-institute-of-linguistics/theses/_files/docs/2001- dyrud-lars.pdf

Hussain, S. (2010). Phonetic correlates of lexical stress in Urdu. (Doctoral dissertation, Northwest University USA). National Language Authority, Islamabad, Pakistan.

IPA. (1999). Handbook of the International Phonetic Association. Cambridge: Cambridge University Press.

Jones, D. (2005). Cambridge English pronouncing dictionary (16th ed.). In P. Roach, J. Hartman, \& J. Setter (Eds.). Cambridge, UK: Cambridge University Press.

Ladefoged, P. N. (2004). Vowels and Consonants (3rd ed.). New York: Black Willey.

Masica, C. P. (1991). The Indo-Aryan languages. Cambridge: Cambridge University Press, Great Britain.

Nayyar, S. (2000-2001). Syllable stress in Urdu. In CRULP Annual Student Report (pp. 202-206). Center for Research in Urdu Language Processing. Retrieved from http://www.cle.org.pk/resources/reports/streport02.htm\#script

Qureshi, B. A. (1992). Standard twentieth century dictionary: Urdu to English. Educational Publishing House. New Delhi, India

Rahman, T. (2014). Pakistani English. (Revised edition) Published by the National Institute of Pakistan Studies, Quaid-e-Azam University, Islamabad.

Thompson, I. $\quad$ (2013). Urdu $\quad$ Language. $\quad$ Retrieved from http://aboutworldlanguages.com/urduhttp://www.phonicsontheweb.com/shortvowels.php

\section{Note}

Note 1. ESL English is as Second Language: Pakistan where official work, school medium, school, and college instruction is in English, where every literate third person understands and writes English is ESL context.

\section{Copyrights}

Copyright for this article is retained by the author(s), with first publication rights granted to the journal.

This is an open-access article distributed under the terms and conditions of the Creative Commons Attribution license (http://creativecommons.org/licenses/by/4.0/). 